All scenarios show significant population increases in the developing countries by $\mathrm{AD} 2030$, though Europe's share decreases from its present $14 \%$ to about $8 \%$ of world population. The projections also show that increased lifeexpectancy will lead to a rapidly-ageing population in developing countries. This will pose severe problems for which their social systems are at present unprepared.

These new world population scenarios show that future trends are not inevitable and there are significant opportunities to influence them. The forthcoming UN International Conference on Population and Development, to be held in Cairo during 5-13 September 1994, will provide an appropriate occasion to discuss these opportunities in an international forum.*

ELISABETH KRIPPL, Head
Public Information
International Institute for Applied
$\quad$ Systems Analysis (IIASA)
A-2361 Laxenburg
Austria.

* See also our book Environmental Challenges, II: Population and Global Security, designed primarily at enlightening ICPD participants on Population-Environment issues, and now fully in press. Ed.

\title{
Climate Change Treaty Goes Into Effect
}

$\mathrm{T}$ he United Nations Framework Convention on Climate Change entered into force on 21 March $1994-90$ days after receiving its 50th ratification and less than two years after it was signed by more than 150 Governments at the Rio 'Earth Summit'. This means that the treaty is now international law and legally binding on its Parties (i.e. ratifying countries), which already include most of the major emitters of 'greenhouse' gases.

The treaty commits developed-country Parties to take measures aimed at returning their emission of carbon dioxide and other 'greenhouse' gases to AD 1990 levels by the year 2000. They were given just six months (until 21 September 1994) to submit information explaining how they plan to meet this and other Convention obligations. These other commitments include protecting and enhancing 'greenhouse' gas 'sinks' and 'reservoirs' (such as forests that absorb carbon dioxide from the atmosphere) and providing financial and technological resources to help developing countries to adapt to climate change and implement the treaty.

\section{Less-developed Countries Favoured}

As for 'developing' countries, they are not required to limit their emissions. However, they (along with developed countries) have accepted commitments to: draw up 'inventories' listing the sources and quantities of their national 'greenhouse" gas emissions, carry out national programmes for mitigating climate change and adapting to its effects, strengthen their scientific and technical research activities, and promote education and public awareness programmes about climate change.

Carbon dioxide is the biggest immediate challenge for developed countries. Most $\mathrm{CO}_{2}$ is emitted by the burning of fossil fuels (oil, gas, and coal), although deforestation and other land clearances also contribute. The national reports that developed countries will soon submit (and update at regular intervals) are likely to describe a mix of regulatory, voluntary, and other, measures for encouraging industry, power stations, households, public authorities, and the transport sector, to control their emissions.

Though prepared for an international forum, these national reports should be essential reading for national policymakers and the informed public. It is at this level of individuals changing how they use energy in their homes and daily lives, of companies responding to incentives for technological innovation and energy conservation, and of local politicians introducing energy-efficiency into transport networks and building codes - that the Climate Change Convention will become a reality for most people. As of early March 1993, two countries (Canada and the
UK) had already submitted their reports under the Convention. Other countries have also published preliminary information; they include Australia, Cuba, the Czech Republic, Germany, Ireland, Italy, Japan, The Netherlands, New Zealand, Norway, Slovakia, Switzerland, and the US.

Meanwhile it has become widely recognized by Governments that bringing developed country emissions back to their AD 1990 levels by the year 2000 will not be enough to achieve the Convention's objective of stabilizing 'greenhouse gas concentrations in the atmosphere at a level that would prevent dangerous anthropogenic interference with the climate system', says Professor Bert Bolin, a leading international scientist from Stockholm, Sweden, who is Chairman of the Intergovernmental Panel on Climate Change (IPCC), which produces highly-influential scientific and technical assessment reports: for 'Stabilizing developed-country emissions of carbon dioxide, as is [currently] being aimed-for, is only a very modest first step towards stabilizing atmospheric concentrations of this gas. Because $\mathrm{CO}_{2}$ emissions remain for such a long time in the atmosphere; even stabilizing total global emissions would not stabilize atmospheric concentrations for several hundred years.'

Professor Bolin highlights total global emissions because, under the treaty, only developed countries must aim to stabilize their emissions. The Convention accepts that the first priority of developing countries is their own economic and social development, and that their emissions will rise as they industrialize. As a result, although developed countries aim to stabilize or even reduce their emissions, total global emissions will still continue to rise. This is why breaking the link between economic development and 'greenhouse' gas emissions is the fundamental, long-term challenge facing the world community.

\section{First Review in March 1995}

According to the treaty, the adequacy of developedcountry commitments must be reviewed at the first session of the Conference of the Parties (COP), the body that will be responsible for overseeing the implementation of the Convention. This session is scheduled for March 1995 in Berlin, Germany. The review will be based in part on a Special Report that the IPCC plans to release, in November 1994 , to update its assessment of the work that is being conducted at research and monitoring centres around the world into the causes and impacts of climate change. The review will also consider the effectiveness of developedcountry efforts to limit emissions as described in the national reports. 
The Berlin meeting will need to finalize many other decisions as well. One of the most important of these relates to the financial arrangements for the treaty. The COP must finalize guidelines on how developed countries should assist developing countries in implementing the Convention. Because so many decisions must be made at the COP's first session, two more intergovernmental meetings will be held to prepare the way. The first will take place during 22 August-2 September 1994 in Geneva, while the second is scheduled for early 1995 in New York.

MiCHAEL WILLIAMS

UNEP/WMO Information Unit on Climate Change

Geneva Executive Centre

CP 356

CH-1219 Châtelaine

Geneva, Switzerland.

\section{The Earth Council and Its Tasks for the Future}

\section{Introduction}

Why are the problems of Environment and Development $(\mathrm{E} / \mathrm{D})$ currently in the doldrums? At the Rio Conference in June 1992, Governments world-wide united to agree on international approaches to the solution of these problems. Why has this optimism been largely replaced by widespread political anxiety in a world now increasingly divided by selfishly national short-term responses to the interrelated problems of poverty, deprivation and illhealth, international trade, and debt, recession, local conflicts, and tribalism? Yet many of these were the very issues that concerned the 187 states which signed the Earth Charter, Agenda 21, and the other agreements, at Rio.

Did they really mean it at the time or are E/D issues turning out to be a ' $\mathrm{cul}$-de-sac' in our thinking, in the manner that so much post-World-War II idealism did when the going got hard? Or are we witnessing the faltering of governments disorientated by the political limbo which has followed the end of the Cold War? Or perhaps we need completely new institutional mechanisms of governance to cope with these problems?

The year 1994 will be a good one for taking stock. Where have our perceptions of $E / D$ come from, and have they really changed human society's view of how it will survive and develop on the Planet Earth? In terms of responses, has anything really been acted on and what has been accomplished? Maybe we are on the wrong track altogether; but in any case, what kind of institutions do we need to help us forward? The Earth Council is clearly one of them; but what will its Programme be like? Who are its supporters and its customers, and do they have the power to effect change and achieve real progress in the right direction?

\section{Earth Council's Establishment}

Founded in September 1992 as a direct result of the 'Earth Summit' held in Rio de Janeiro, Brazil, in June 1992, the Earth Council is a non-governmental organization of important potential.

The 'Earth Summit' produced agreement on basic principles incorporated in the Rio Declaration, and a comprehensive and far-ranging programme of action, Agenda 21 , which is designed to launch the world community onto a new pathway towards a more secure, sustainable, and equitable, future in environmental, economic, and social, terms. But the ultimate impact of these agreements - and the international environmental treaties - will depend on effective arrangements for public monitoring, reviewing, and facilitating, the follow-up and implementation of these decisions.
The unprecedented level of involvement in the 'Earth Summit' of those outside government was the key to its political significance, and the Earth Council has been established to maintain this global effort and broaden the opportunities for an expanded role of independent organizations - particularly those of a 'grassroots' nature - to ensure transparency, accountability, and real public participation.

The Earth Council consists of twenty-one members who are broadly representative of the principal regions of the world and the various sectors of the civil society, each appointed in his or her personal capacity. It will seek to give voices to concerned people from around the world especially those who are not sufficiently heard or heeded in policy and decision-making processes. It will attempt to facilitate redress of grievances and equitable resolution of disputes through a global ombudsman function, investigating and reporting on critical environment and development issues that affect people or violate the rights stemming from the Rio agreements.

\section{Objectives of the Earth Council}

- To facilitate and support peoples' initiatives on behalf of the Earth, particularly in implementation of the governmental and nongovernmental results of the 'Earth Summit';

- To help to ensure that the experience, the concerns, and the interests, of people 'at the grassroots' are brought to bear at all levels of policy- and decision-making;

- To promote greater-than-current interaction and communication between scientists, other experts, and native peoples, on important environment and development issues;

- To promote public awareness in respect of environment and development issues, and to help to ensure that public dialogue on these issues is illuminated by the objective knowledge and opinions of scientists and other experts; and

- To monitor, complement, and support, the work and mission of the United Nations Commission on Sustainable Development.

\author{
GORDON GOODMAN, Chairman \\ International Scientific Committee \\ International Academy of the Environment \\ Chemin de Conches 4 \\ 1231 Conches \\ Geneva, Switzerland; \\ formerly Founding Executive Director, \\ Stockholm Environment Institute.
}

